\title{
Reduction of renal function during mechanical ventilation of healthy lungs in an animal biomodel
}

\author{
Kobr $\mathrm{J}^{1}$, Fremuth $\mathrm{J}^{1}$, Sasek L ${ }^{1}$, Jehlicka $\mathrm{P}^{1}$, Hrdlicka $\mathrm{R}^{1}$, Racek $\mathrm{J}^{2}$, Hes $\mathrm{O}^{3}$, Koppl $\mathrm{J}^{4}$, Pizingerova $\mathrm{K}^{1}$ \\ Department of Paediatrics - PICU, Charles University in Prague, Faculty of Medicine in Pilsen, Czech Republic. \\ kobr@fnplzen.cz
}

\begin{abstract}
Objectives: To identify factors involved in reno-pulmonary interactions during mechanical ventilation. Materials and methods: The study included a total of 25 domestic piglets. The animals were divided into three groups based on different strategies of ventilation. Group A; spontaneously breathing piglets; group B animals ventilated with tidal volume of $6 \mathrm{ml} . \mathrm{kg}^{-1}$ and group $\mathrm{C}$ with animals ventilated with tidal volume $10 \mathrm{ml} . \mathrm{kg}^{-1}$. Clinical monitoring and laboratory tests were performed for all groups at baseline and then at 1 hour and 12 hours for groups B and C. Ventilation indices, hemodynamics, urine output, creatinine clearance, glomerular filtration index, fractional excretion of sodium, free water clearance and tissue samples were recorded. The data obtained were statistically analysed.

Results: Lower creatinine clearance and renal indices were seen in group B $(p<0.05)$ and in group C $(p<$ $0.001)$ at 1 hour, and a difference in urine output for group $C(p<0.01)$ compared to group $A$ was observed. At 12 hours, there was a further reduction in creatinine clearance and renal indices for group B $(p<0.05)$ and group $C(p<0.01)$. The lung mechanics and hemodynamics were not significantly influenced.

Conclusions: The study showed a causal relationship between renal dysfunction and positive pressure mechanical ventilation with respect to tidal volume and time (Tab. 4, Fig. 2, Ref. 17). Text in PDF www.elis.sk.

Key words: renal, dysfunction, interactions, ventilation, tidal, volume.
\end{abstract}

\begin{abstract}
Abbreviations: $\mathrm{KJ}$ - carried out the experimental work, designed the study, performed statistical analysis, supervised the preparation of this manuscript and drafted the manuscript, FJ - carried out the experimental work, coordinated the study, SL - carried out the experimental work, collected the data, JP - carried out the experimental work, HR - carried out the experimental work, $\mathrm{RJ}$ - carried out the biochemical analysis, $\mathrm{HO}$ - carried out the histological assessment, $\mathrm{KJ}$ - collected the data, $\mathrm{PK}$ - carried out the experimental work, collected the data
\end{abstract}

Respiratory failure in paediatric intensive care units is the most common indicator of positive pressure mechanical ventilation. The strategy of mechanical ventilation has demonstrable influence on the development of adverse organ interactions, which can include renal dysfunction with fluid retention, increasing the morbidity and mortality of critically ill children. Positive pressure mechanical ventilation induced both local and systemic inflammatory re-

${ }^{1}$ Department of Paediatrics - PICU, Charles University in Prague, Faculty of Medicine in Pilsen, Czech Republic, ${ }^{2}$ Department of Clinical biochemistry and haematology, Charles University in Prague, Faculty of Medicine in Pilsen, Czech Republic, ${ }^{3}$ Sikl's Pathological Anatomy Institute, Faculty Hospital in Pilsen, Czech Republic, and ${ }^{4}$ Department of Paediatrics Anaesthesiology and Intensive Care, Comenius University and Children University Hospital Bratislava, Slovakia

Address for correspondence: J. Kobr, MD, PhD, Department of Paediatrics, Charles University in Prague, Faculty of Medicine in Pilsen, Alej Svobody 80, CZ-304 60 Pilsen, Czech Republic.

Phone: +420.377104330

Acknowledgements: The study was supported by research grants MSM0021620819 and PRVOUK P-36 sponses, and a number of clinical and experimental studies support the hypothesis that the adverse reactions are caused by circulating mediators of the systemic inflammatory response (1-4). Specifically in the kidney, there are changes in microcirculation, molecular interactions and a decline in glomerular filtration (5-8). Previous studies confirm the adverse influence of mechanical ventilation, including expression of circulating mediators such as pro-inflammatory cytokines, cell adhesive molecules and chemokines (4).

\section{Aims of the study}

In light of these data, this study focused exclusively on renal function and morphology using a clinically relevant animal biological model undergoing twelve hours of positive pressure mechanical ventilation, in an effort to confirm reduction in renal function and define significant factors.

\section{Material and methods}

The experimental, randomized and comparative study was approved by the Academic ethics committee of the Charles University in Prague. The study was performed at the Faculty of Medicine in an accredited experimental surgical laboratory, Charles University in Pilsen (Prague).

\section{Animal preparation}

The 25 piglets used in this study were obtained from a controlled breeding station for domestic swine. Piglets were 6 weeks of age and had an average weight of $22.7 \mathrm{~kg}$ (range 18.5-27.0 kg). 
The animals were premedicated intramuscularly with atropine (0.07 mg.kg-1 Atropin; Hoechst-Biotika, Slovak Republic) and azaperon (5.0 mg. $\mathrm{kg}^{-1}$, Stresnil; Janssen Pharmaceuticals N.V., Belgium) thirty minutes before general anesthesia. Thiopental (10.0 mg.kg ${ }^{-1}$, Thiopental; VUAB Pharma, Czech Republic) was administered intravenously for the induction of anaesthesia and piglets were intubated with endotracheal tube (Kendall, ID 5.5 mm; GPS Prague, Ltd., Czech Republic). The administration of thiopental was continued at $2.0 \mathrm{mg} . \mathrm{kg}^{-1} \mathrm{per}$ hour intravenously and bolus doses of fentanyl (5.0 ug. $\mathrm{kg}^{-1}$, Fentanyl; Hexal AG, Germany) were used for analgesia (8). A central venous catheter (Certofix Paed 5F; B.Braun, Germany) was inserted into the internal jugular vein and an arterial line (Vygon ArterySet, 24G; Germany) was surgically inserted into the femoral artery. Urinary drainage was accomplished by surgical cystostomy using a permanent urinary catheter (Cystofix 10F; Arrow International CR, Germany). All the animals were given Ringer's venous infusion $2.7 \mathrm{ml} . \mathrm{kg}^{-1}$ per hour (Ringer, Infusia, Czech Republic) during the study.

Animals were divided into three groups based on different strategies of ventilation. The controls (Group A, $n=5$ ) were intubated and spontaneously breathing piglets. Piglets in groups $\mathrm{B}$ and $C$ were intubated and mechanically ventilated lying on side in pressure-controlled mode (Elema Siemens 900 C; Germany) at a constant ventilatory rate of 26 breaths per min, $6 \mathrm{cmH}_{2} \mathrm{O}$ positive end-expiratory pressure (PEEP) and fraction of inspired oxygen $\left(\mathrm{FiO}_{2}\right)$ at 0.21 . The animals in Group $\mathrm{B}(\mathrm{n}=10)$ were ventilated with a tidal volume $\left(\mathrm{V}_{\mathrm{T}}\right)$ of $6 \mathrm{mlkg}^{-1}$ and in Group C $(\mathrm{n}=10)$, the tidal volume was $10 \mathrm{mlkg}^{-1}$. The functions of extra-pulmonary organs were purposely not influenced pharmacologically such as with diuretics, vasopressors or inotropes.

\section{Protocol of the study}

Samples were collected for Groups A-C at one hour (time-1, $\left.A, B_{1}, C_{1}\right)$ and twelve hours (time-12) for groups B and $C\left(B_{12}, C_{12}\right)$ after initiating ventilation, blood was collected from the arterial line and urine from the urinary cystostomy catheter. After sampling and measurements at time- 1 were spontaneously breathing animals (the control group A) connected to mechanical ventilation and under general anesthesia incorporated into the surgical experiment in another study.

The following parameters were measured in serum and urine: urea, creatinine, $\mathrm{Na}^{+}, \mathrm{K}^{+}, \mathrm{Cl}^{-}$, osmolality, glucose and acid-base balance in arterial blood. ECG, heart rate (HR; pulse per min), pulse oximetry $\left(\mathrm{SpO}_{2} ; \%\right)$, end-tidal carbon dioxide $\left(\mathrm{EtCO}_{2} ; \mathrm{kPa}\right)$, central venous pressure (CVP; mmHg), systolic blood pressure (SBP; mmHg), mean arterial pressure (MAP; $\mathrm{mmHg}$ ) and diastolic blood pressure (DBP; mmHg) were recorded at the same times on a cardio-monitor (Nihon Kohden; Japan). Urinary output and core temperature were recorded hourly.

The values of peak inspiratory pressure (PIP; $\mathrm{cmH}_{2} \mathrm{O}$ ), mean airway pressure (Paw; $\left.\mathrm{cmH}_{2} \mathrm{O}\right)$, respiratory rate (RR; spontaneous breths.min ${ }^{-1}$ ), breath rate (BR; artificial breths.min ${ }^{-1}$ ), endexpiratory pressure (PEEP; $\left.\mathrm{cmH}_{2} \mathrm{O}\right)$, tidal volume $\left(\mathrm{V}_{\mathrm{T}} ; \mathrm{ml}^{-\mathrm{kg}^{-1}}\right)$, minute ventilation $\left(\mathrm{V}_{\mathrm{E}} ; \mathrm{ml} . \mathrm{min}^{-1}\right)$, fraction of inspired oxygen $\left(\mathrm{FiO}_{2}\right.$; \%) were recorded. The quality of ventilation was evalu- ated by the following indices: alveolar-arterial oxygen difference $\left(\mathrm{AaDO}_{2} ; \mathrm{kPa}\right)$, arterio-alveolar oxygen difference $\left(\mathrm{a} / \mathrm{ADO}_{2} ; \mathrm{kPa}\right)$, oxygenation index (OI; -), hypoxemic ratio $\left(\mathrm{PaO}_{2} / \mathrm{FiO}_{2} ; \mathrm{mmHg}\right)$, dead space/tidal volume ratio $\left(\mathrm{V}_{\mathrm{D}} / \mathrm{V}_{\mathrm{T}} ; \%\right)$, ventilation index (VI; -), dynamic lung compliance $\left(\mathrm{C}_{\mathrm{dyn}} ; \mathrm{ml}^{\mathrm{cm}} \mathrm{cm}_{2} \mathrm{O}^{-1} \cdot \mathrm{kg}^{-1}\right)$ and airway resistance $\left(\mathrm{R}_{\mathrm{aw}} ; \mathrm{cmH}_{2} 0 . \mathrm{l}^{-1} \cdot \mathrm{s}^{-1}\right)$.

Renal function was assessed by urinary output (UO; $\mathrm{ml}^{\mathrm{kg}}{ }^{-1}$. hod $\left.^{-1}\right)$, creatinine clearance $[\mathrm{CrCl}=(\mathrm{u}$-creatinine $\mathrm{x}$ urine output $) / \mathrm{s}-$ creatinine; $\left.\mathrm{ml} \cdot \mathrm{min}^{-1}\right]$, fractional excretion of sodium $[\mathrm{FeNa}=(\mathrm{u}-$ $\mathrm{Na} / \mathrm{s}-\mathrm{Na}$ ) / (u-creatinine/s-creatinine); -], glomerular filtration index [GFI = u-Na / (u-creatinine/s-creatinine)]; -), free water clearance $[\mathrm{Cfw}=$ urine output-(urine output $\mathrm{x}$ u-osmolality)/sosmolality; ml.mmol-1 $\mathrm{kg}^{-1}$ ] and ratio of potassium to sodium in the urine (u-K/u-Na ratio; -) (10). At the end of the procedure, samples of kidney tissue were collected for histological examination. Tissue was fixed with $10 \%$ formalin solution, stained with hematoxylin \& eosin and examined by optical microscope with a 40 times magnification.

All animals were euthanized at the end of the procedure by an intravenous bolus of cardioplegic solution (10\% Thomas solution; 15 ml. $\mathrm{kg}^{-1}$ ) while under general anaesthesia. The carcasses were disposed of in accordance with regulations of the Czech Republic and European Union.

\section{Statistical analysis}

The data were compared as follows: At time-1, groups A, B and $C$ were compared while at time-12, exclusively the ventilated animals (groups B and C) were compared. Descriptive quantitative non-parametric (median, Q1st-Q3rd) analyses, paired t-test (Students t-test) and unpaired t-test (Shapiro-Wilcoxon) were performed on the data. Correlations were analyzed by momental replication analysis (Pearson), linear and polynominal regressions. Data were analyzed by Analyse-it211 (Software, Ltd, Peltier Technical Services, Inc.; USA). The values were presented as median and interquartile range (Q1st - Q3rd). Values of $\mathrm{p}<0.05$ were considered statistically significant.

\section{Results}

The indices of ventilation, basic hemodynamic parameters, urine output, creatinine clearance and renal indices in Group A are summarized in Table 1 . These values of clinical measurements and laboratory tests were used as controls for Groups B and C in time-1.

In the time- $1 \mathrm{AaDO}_{2}(\mathrm{p}<0.05)$, OI $(\mathrm{p}<0.05)$, GFI $(\mathrm{p}<0.01)$, FeNa ( $<<0.05)$, u-K/u-Na ratio ( $\mathrm{p}<0.05$ ) were higher and conversely $\mathrm{V}_{\mathrm{D}} / \mathrm{V}_{\mathrm{T}}(\mathrm{p}<0.05), \mathrm{CrCl}(\mathrm{p}<0.05)$ and Cfw $(\mathrm{p}<0.05)$ were lower in group $\mathrm{B}$ compared with group $\mathrm{A}$. After twelve hours of ventilation (time-12) were significantly lower $\mathrm{V}_{\mathrm{D}} / \mathrm{V}_{\mathrm{T}}(\mathrm{p}<0.05)$, but also $\mathrm{C}_{\mathrm{dyn}}(\mathrm{p}<0.05), \mathrm{CrCl}(\mathrm{p}<0.05)$, and other renal indices data in comparison with the time-1. Blood circulation parameters were not significantly altered.

Summary of the data obtained in group B and the differences during the study are shown in Table 2.

Significant differences of monitored parameters were recorded in group C. In group $\mathrm{CAaDO}_{2}(\mathrm{p}<0.05)$ and $\mathrm{OI}(\mathrm{p}<0.01)$ were 
Tab. 1. Spontaneously breathing piglets in Group A, reference values the study.

\begin{tabular}{lc}
\hline Parameters & Group A \\
\hline $\mathrm{AaDO}_{2}$ & $1.03(0.66 ; 1.42)$ \\
$\mathrm{a} / \mathrm{A} \mathrm{DO}_{2}$ & $0.82(0.74 ; 0.92)$ \\
$\mathrm{OI}$ & $4.06(3.08 ; 4.77)$ \\
$\mathrm{PaO}_{2} / \mathrm{FiO}_{2}$ & $360.5(332.6 ; 377.4)$ \\
$\mathrm{VI}$ & $22.86(18.66 ; 24.12)$ \\
$\mathrm{V}_{\mathrm{D}} / \mathrm{V}_{\mathrm{T}}$ & $22.25(15.03 ; 28.45)$ \\
$\mathrm{C}_{\text {dyn }}$ & $0.63(0.52 ; 0.69)$ \\
$\mathrm{R}_{\text {awe }}$ & $0.95(0.66 ; 0.97)$ \\
$\mathrm{CVP}$ & $0.97(0.53 ; 1.31)$ \\
$\mathrm{SBP}$ & $99(89.51 ; 100.76)$ \\
$\mathrm{MAP}$ & $76.5(67.32 ; 84.77)$ \\
$\mathrm{DBP}$ & $66(59.74 ; 70.46)$ \\
$\mathrm{UO}$ & $2.3(1.75 ; 2.63)$ \\
$\mathrm{CrCl}$ & $0.18(0.15 ; 0.21)$ \\
$\mathrm{Cfw}$ & $-0.5(-0.32 ;-1.17)$ \\
$\mathrm{GFI}$ & $958.33(741.59 ; 900.33)$ \\
$\mathrm{FeNa}$ & $7.0(3.89 ; 9.22)$ \\
$\mathrm{u}-\mathrm{K} / \mathrm{u}-\mathrm{Na}$ & $0.28(0.20 ; 0.35)$ \\
\hline $\mathrm{AaDO}$ &
\end{tabular}

$\mathrm{AaDO}_{2}$ - alveolar-arterial oxygen difference $(\mathrm{kPa}) ; \mathrm{a} / \mathrm{ADO}_{2}$-arterial-alveolar oxygen difference ( $\mathrm{kPa})$; OI - oxygenation index (-); $\mathrm{paO}_{2} / \mathrm{FiO}_{2}$ - hypoxemic ratio (mmHg); $\mathrm{VI}$ - ventilation index (-); $\mathrm{V}_{\mathrm{D}} / \mathrm{V}_{\mathrm{T}}$ - dead space-to-tidal volume ratio (\%); $\mathrm{C}_{\mathrm{dyn}}-$ dynamic lung compliance (ml.cmH $\left.\mathrm{O}^{-1} \cdot \mathrm{kg}^{-1}\right) ; \mathrm{R}_{\mathrm{aw}}$ - airway resistance $\left.\mathrm{cmH}_{2} \mathrm{O}^{-1} \cdot \mathrm{s}^{-1}\right)$; CVP - central venous pressure (mmHg); SBP - systolic blood pressure (mmHg); $\mathrm{MAP}$ - mean arterial pressure ( $\mathrm{mmHg}$ ); $\mathrm{DBP}$ - diastolic blood pressure ( $\mathrm{mmHg}$ ); UO - urine output $\left(\mathrm{ml} \mathrm{kg}^{-1} \cdot \mathrm{h}^{-1}\right) ; \mathrm{CrCl}$ - creatinine clearance $\left(\mathrm{ml} \cdot \mathrm{min}^{-1}\right) ; \mathrm{Cfw}$ - free water clearance $\left(\mathrm{ml}^{\mathrm{mmol}}{ }^{-1} \cdot \mathrm{kg}^{-1}\right)$; GFI - glomerular filtration index (-); FeNa - fractional excretion of sodium (-); $\mathrm{u}-\mathrm{K} / \mathrm{u}-\mathrm{Na}$ - ratio levels of potassium to sodium in urine. All data are expressed as median and interquartiler range $\left(\mathrm{Q}^{\text {1st }} ; \mathrm{Q}^{\text {3rd }}\right)$

\section{Tab. 2. Data differences in Group B.}

\begin{tabular}{lccc}
\hline Parameters & $\mathrm{B}_{1}$ & $\mathrm{~B}_{12}$ & Values $\mathrm{p}^{<}$ \\
\hline $\mathrm{AaDO}_{2}$ & $4.14(1.99 ; 35.87)$ & $10.94(4.96 ; 31.30)$ & $\mathrm{NS}$ \\
$\mathrm{a} / \mathrm{ADO}_{2}$ & $0.79(0.41 ; 0.90)$ & $0.54(0.29 ; 0.67)$ & $\mathrm{NS}$ \\
$\mathrm{OI}$ & $1.47(1.31 ; 4.37)$ & $1.91(1.44 ; 3.97)$ & 0.05 \\
$\mathrm{PaO}_{2} / \mathrm{FiO}_{2}$ & $380.51(378.02 ; 420.60)$ & $285.38(262.85 ; 399.90)$ & $\mathrm{NS}$ \\
$\mathrm{VI}$ & $18.78(12.38 ; 26.21)$ & $22.42(23.42 ; 30.36)$ & $\mathrm{NS}$ \\
$\mathrm{V}_{\mathrm{D}} / \mathrm{V}_{\mathrm{T}}$ & $27.44(20.91 ; 39.16)$ & $21.49(20.83 ; 22.47)$ & 0.01 \\
$\mathrm{C}_{\text {dyn }}$ & $0.57(0.51 ; 0.59)$ & $0.46(0.42 ; 0.57)$ & 0.05 \\
$\mathrm{R}_{\text {awe }}$ & $0.84(0.60 ; 1.00)$ & $1.17(1.03 ; 1.29)$ & $\mathrm{NS}$ \\
$\mathrm{CVP}$ & $1.97(0.85 ; 2.07)$ & $2.05(1.56 ; 2.25)$ & $\mathrm{NS}$ \\
$\mathrm{SBP}$ & $99.5(95 ; 98)$ & $117(108 ; 122)$ & $\mathrm{NS}$ \\
$\mathrm{MAP}$ & $69(64 ; 86)$ & $95(87 ; 95)$ & $\mathrm{NS}$ \\
$\mathrm{DBP}$ & $61(56 ; 81)$ & $83(80 ; 89)$ & $\mathrm{NS}$ \\
$\mathrm{UO}$ & $1.7(1.4 ; 1.9)$ & $1.5(0.95 ; 1.93)$ & $\mathrm{NS}$ \\
$\mathrm{CrCl}$ & $0.234(0.18 ; 0.25)$ & $0.12(0.10 ; 0.15)$ & 0.05 \\
$\mathrm{Cfw}$ & $-0.4(-0.85 ; 0.13)$ & $-0.7(-0.92 ; 0.17)$ & $\mathrm{NS}$ \\
$\mathrm{GFI}$ & $386.36(121.21 ; 2891.89)$ & $1258.06(641.79 ; 1282.06)$ & 0.01 \\
$\mathrm{FeNa}$ & $2.76(0.87 ; 2.71)$ & $9.39(4.55 ; 12.53)$ & 0.01 \\
u-K/u-Na & $0.48(0.26 ; 0.53]$ & $1.08(0.95 ; 1.36)$ & 0.01 \\
\hline
\end{tabular}

$\mathrm{AaDO}_{2}$ - alveolar-arterial oxygen difference $(\mathrm{kPa})$; $\mathrm{a} / \mathrm{ADO}_{2}$ - arterial-alveolar oxygen difference (kPa); OI - oxygenation index (-); $\mathrm{paO}_{2} / \mathrm{FiO}_{2}$ - hypoxemic ratio (mmHg); $\mathrm{VI}$ - ventilation index (-); $\mathrm{V}_{\mathrm{D}} / \mathrm{V}_{\mathrm{T}}$ - dead space-to-tidal volume ratio (\%); $\mathrm{C}_{\mathrm{dyn}}$ - dynamic lung compliance $\left(\mathrm{ml} \cdot \mathrm{cmH}_{2} \mathrm{O}^{-1} \cdot \mathrm{kg}^{-1}\right) ; \mathrm{R}_{2}$ - airway resistance $\left.\mathrm{cmH}_{2} \mathrm{O}^{-1} \cdot \mathrm{s}^{-1}\right)$; CVP - central venous pressure (mmHg); SBP - systolic blood pressure (mmHg) - MAP - mean arterial pressure (mmHg); DBP - diastolic blood pressure (mmHg); UO urine output $\left(\mathrm{ml} \cdot \mathrm{kg}^{-1} \cdot \mathrm{h}^{-1}\right) ; \mathrm{CrCl}$ - creatinine clearance $\left(\mathrm{ml} \cdot \mathrm{min}^{-1}\right)$; $\mathrm{Cfw}$ - free water clearance $\left(\mathrm{ml} . \mathrm{mmol}^{-1} \cdot \mathrm{kg}^{-1}\right)$; GFI - glomerular filtration index (-); FeNa - fractional excretion of sodium (-); $\mathrm{u}-\mathrm{K} / \mathrm{u}-\mathrm{Na}$ - ratio levels of potassium to sodium in urine. $\mathrm{B}_{1}$ - group $\mathrm{B}$ - the data in time- 1 - $\mathrm{B}_{12}$ - group $\mathrm{B}$ - the data in time-12. All data are expressed as median and interquartiler range $\left(\mathrm{Q}^{1 \mathrm{st}} ; \mathrm{Q}^{3 \mathrm{rd}}\right)$

higher, but UO ( $\mathrm{p}<0.05)$, $\mathrm{CrCl}(\mathrm{p}<0.05)$, Cfw (p $<0.05)$, GFI $(\mathrm{p}<0.001)$, FeNa $(\mathrm{p}<0.01)$ lower and also $\mathrm{u}-\mathrm{K} / \mathrm{u}-\mathrm{Na}$ ratio $(\mathrm{p}<$ 0.01 ) was lower compared with group $A$. In group $C$ were also
Tab. 3. Data differences in Group C.

\begin{tabular}{lccc}
\hline Parameters & $\mathrm{C}_{1}$ & $\mathrm{C}_{12}$ & Values $\mathrm{p}<$ \\
\hline $\mathrm{AaDO}_{2}$ & $0.737(-0.56 ; 3.16)$ & $2.74(0.11 ; 31.29)$ & 0.05 \\
$\mathrm{a} / \mathrm{ADO}_{2}$ & $0.94(0.73 ; 1.04)$ & $0.78(0.33 ; 0.99)$ & $\mathrm{NS}$ \\
$\mathrm{OI}$ & $2.06(1.97 ; 3.06)$ & $3.37(2.37 ; 5.63)$ & 0.05 \\
$\mathrm{PaO}_{2} / \mathrm{FiO}_{2}$ & $382.65(300.40 ; 518.55)$ & $346.89(195.26 ; 443.09)$ & $\mathrm{NS}$ \\
$\mathrm{VI}$ & $24.03(20.83 ; 28.65)$ & $35.27(28.59 ; 44.57)$ & $\mathrm{NS}$ \\
$\mathrm{V}_{\mathrm{D}} / \mathrm{V}_{\mathrm{T}}$ & $28.36(28.35 ; 38.18)$ & $39.02(16.05 ; 43.36)$ & $\mathrm{NS}$ \\
$\mathrm{C}_{\text {dyn }}$ & $0.63(0.63 ; 0.75)$ & $0.61(0.54 ; 0.66)$ & $\mathrm{NS}$ \\
$\mathrm{R}_{\text {awe }}$ & $1.22(1.03 ; 1.22)$ & $1.25(1.17 ; 1.42)$ & $\mathrm{NS}$ \\
$\mathrm{CVP}$ & $1.95(1.22 ; 2.02)$ & $2.21(1.87 ; 2.30)$ & $\mathrm{NS}$ \\
$\mathrm{SBP}$ & $110(108 ; 117)$ & $112(95 ; 134)$ & $\mathrm{NS}$ \\
$\mathrm{MAP}$ & $73(69 ; 73)$ & $62(59 ; 82)$ & $\mathrm{NS}$ \\
$\mathrm{DBP}$ & $56(54 ; 65)$ & $59(53 ; 82)$ & $\mathrm{NS}$ \\
$\mathrm{UO}$ & $1.2(0.9 ; 1.8)$ & $0.6(0.5 ; 1.0)$ & 0.05 \\
$\mathrm{CrCl}$ & $0.61(0.57 ; 0.65)$ & $0.25(0.29 ; 0.30)$ & 0.05 \\
$\mathrm{Cfw}$ & $-1.0(-1.1 ;-0.02)$ & $-0.95(-0.95 ; 9.0)$ & $\mathrm{NS}$ \\
$\mathrm{GFI}$ & $54.70(54.69 ; 87.32)$ & $180.95(137.50 ; 375.00)$ & 0.01 \\
$\mathrm{FeNa}$ & $0.40(0.30 ; 0.40)$ & $1.36(0.95 ; 2.82)$ & 0.001 \\
$\mathrm{u}-\mathrm{K} / \mathrm{u}-\mathrm{Na}$ & $0.56(0.51 ; 0.66)$ & $1.41(1.07 ; 1.46)$ & 0.05 \\
\hline $\mathrm{AaDO}$
\end{tabular}

$\mathrm{AaDO}_{2}$ - alveolar-arterial oxygen difference $(\mathrm{kPa})$; a/ADO - arterial-alveolar oxygen difference $(\mathrm{kPa})$; OI - oxygenation index $(-)$; $\mathrm{paO}_{2} / \mathrm{FiO}_{2}$ - hypoxemic ratio $(\mathrm{mmHg})$; $\mathrm{VI}$ - ventilation index (-); $\mathrm{V}_{\mathrm{D}} / \mathrm{V}_{\mathrm{T}}$ - dead space-to-tidal volume ratio (\%); $\mathrm{C}_{\mathrm{dyn}}-$ dynamic lung compliance $\left(\mathrm{ml} . \mathrm{cmH} \mathrm{O}^{-1} \mathrm{~kg}^{-1}\right) ; \mathrm{R}$ - airway resistance $\left.\mathrm{cmH} \mathrm{O}^{-1} \cdot \mathrm{s}^{-1}\right)$; CVP - central venous pressure (mmHg); $\mathrm{SBP}$ - systolic blood pressure (mmHg) - MAP - mean arterial pressure (mmHg); DBP - diastolic blood pressure (mmHg); UO urine output $\left(\mathrm{ml} . \mathrm{kg}^{-1} \cdot \mathrm{h}^{-1}\right)$; $\mathrm{CrCl}$ - creatinine clearance $\left(\mathrm{ml}^{\left.-\mathrm{min}^{-1}\right)}\right.$; $\mathrm{Cfw}$ - free water clearance (ml.mmol $\left.{ }^{-1} \cdot \mathrm{kg}^{-1}\right)$; GFI - glomerular filtration index (-); FeNa - fractional excretion of sodium $(-)$; u-K/u-Na - ratio levels of potassium to sodium in urine. $\mathrm{C}_{1}$ - group $\mathrm{C}$ - the data in time- $1 ; \mathrm{C}_{12}$ - group $\mathrm{C}$ - the data in time- 12 . All data are expressed as median and interquartiler range $\left(\mathrm{Q}^{1 \text { st }} ; \mathrm{Q}^{\text {3rd }}\right)$.

Tab. 4. Pearson's correlation between the renal and ventilation indices.

\begin{tabular}{lccc}
\hline $\begin{array}{l}\text { Dependent } \\
\text { variable }\end{array}$ & $\begin{array}{c}\text { Independent } \\
\text { variable }\end{array}$ & $\begin{array}{c}\text { Pearsons } \\
\text { correlation } \mathrm{r}=\end{array}$ & $\begin{array}{c}\text { Values } \\
\mathrm{p}<\end{array}$ \\
\hline \multirow{3}{*}{$\mathrm{Cfw}$} & $\mathrm{AaDO}_{2}$ & 0.561 & 0.05 \\
& $\mathrm{R}_{\text {awe }}$ & -0.889 & 0.001 \\
\hline \multirow{2}{*}{$\mathrm{GFI}$} & $\mathrm{C}_{\mathrm{dyn}}$ & 0.885 & 0.001 \\
\hline \multirow{2}{*}{ FeNa } & $\mathrm{PaO}_{2} / \mathrm{FiO}_{2}$ & -0.651 & 0.01 \\
& $\mathrm{C}_{\mathrm{dyn}}$ & 0.542 & 0.05 \\
\hline & $\mathrm{V}_{\mathrm{D}} / \mathrm{V}_{\mathrm{T}}$ & -0.603 & 0.05 \\
& $\mathrm{PaO}_{2} / \mathrm{FiO}_{2}$ & -0.634 & 0.05 \\
& $\mathrm{C}_{\mathrm{dyn}}$ & 0.532 & 0.05 \\
\hline
\end{tabular}

$\mathrm{Cfw}$ - free water clearance $\left(\mathrm{ml} \cdot \mathrm{mmol}^{-1} \cdot \mathrm{kg}^{-1}\right)$; GFI - glomerular filtration index (-); $\mathrm{FeNa}$ - fractional excretion of sodium $(-)$. $\mathrm{AaDO}_{2}-$ alveolar-arterial oxygen difference $(\mathrm{kPa}) ; \mathrm{paO}_{2} / \mathrm{FiO}_{2}$ - hypoxemic ratio $(\mathrm{mmHg}) ; \mathrm{V}_{\mathrm{D}} / \mathrm{V}_{\mathrm{T}}$ - dead space-to-tidal

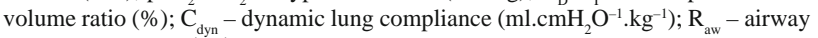
resistance $\left(\mathrm{cmH}_{2} \mathrm{O}^{-1} \cdot \mathrm{s}^{-1}\right)$

$\mathrm{AaDO}_{2}(\mathrm{p}<0.05)$, OI ( $\left.\mathrm{p}<0.05\right), \mathrm{CrCl}(\mathrm{p}<0.01)$, Cfw ( $\left.\mathrm{p}<0.05\right)$, FeNa ( $<<0.05)$ and $\mathrm{u}-\mathrm{K} / \mathrm{u}-\mathrm{Na}$ rato $(\mathrm{p}<0.01)$ higher, but GFI ( $<0.01)$ and UO $(\mathrm{p}<0.05)$ were lower compared with group B. After twelve hours (time-12) $\mathrm{AaDO}_{2}$ and OI were significantly higher in this group. OI $(p<0.05)$, and VI $(p<0.05)$ were higher compared with group B. Changes in blood circulation were not significant. With the exception of Cfw renal function parameters were even significantly lower in this group. All parameters of renal function with the exception of UO $(p<0.05)$ were also lower compared to group B.

Overview of the data obtained in Group $\mathrm{C}$ and the differences during the study lare shown in Table 3.

Regression analysis of the data obtained in the study showed a significant correlation between the data obtained regarding qual- 


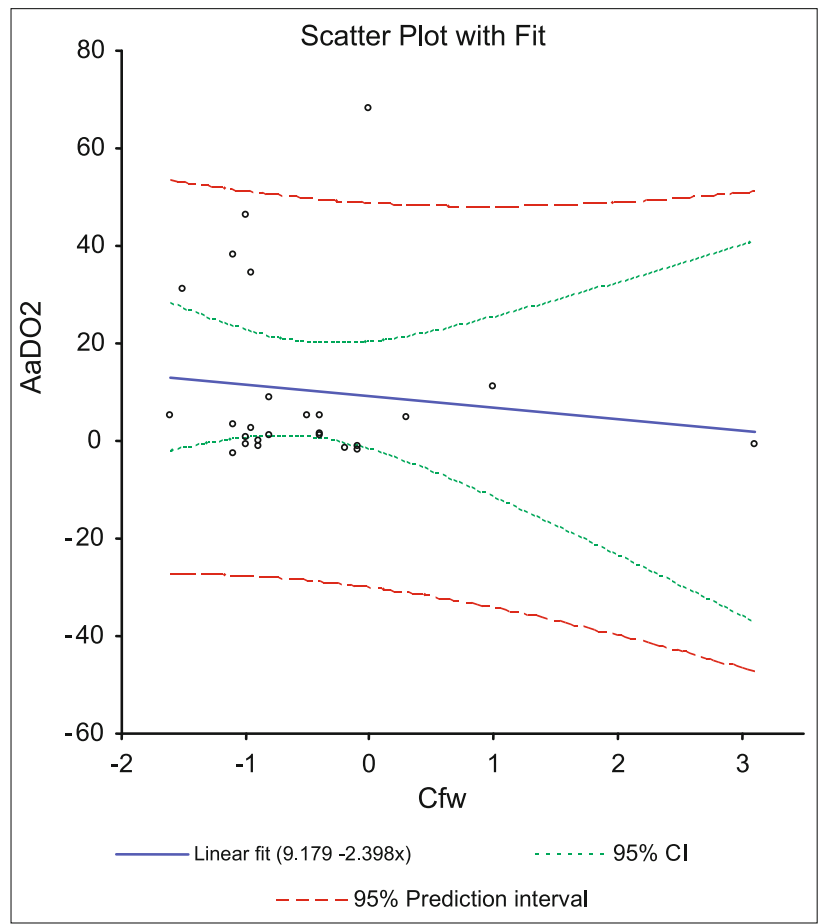

Fig. 1. Free water clearance vs. alveolar-arterial oxygen difference in polynomial regression analysis. $\mathrm{Cfw}$ - free water clearance as dependent variable on axis $\mathbf{x} ; \mathbf{A a D O}_{2}$ - alveolar-arterial oxygen difference as independent variable on axis y.

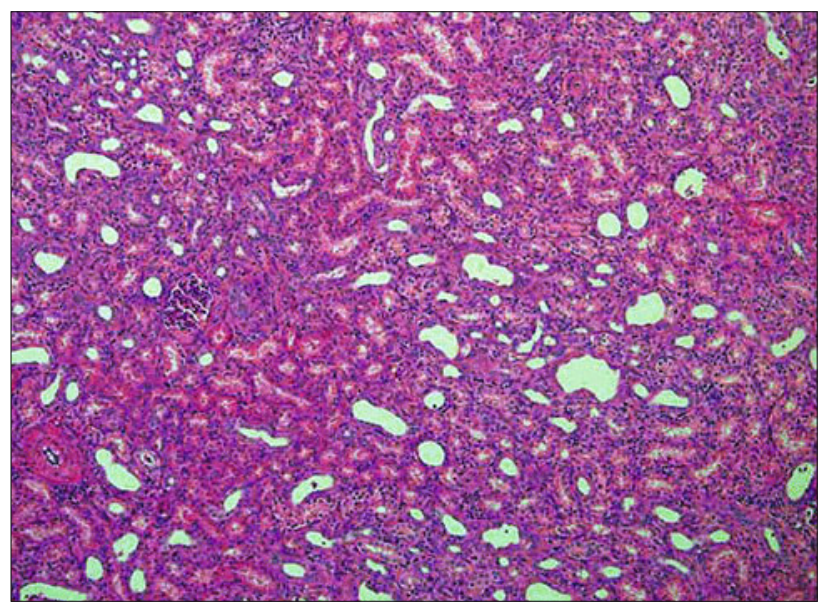

Fig. 2. Optical microscope image of piglet's kidney tissue. Renal tissue of the animal ventilated 12 hours with higher tidal volume $\left(V_{T}=\right.$ $\left.10 \mathrm{ml} . \mathrm{kg}^{-1}\right)$. Cortex and renal medulla are without pathological findings.40 $\mathrm{x}$ magnifications.

ity of ventilation and renal function. The authors determined the data of renal function as dependent variables and data, expressing the quality of ventilation as independent variables. All relevant correlation between dependent and independent parameters are shown in Table 4.

The relationship between the parameters of Cfw and $\mathrm{AaDO}_{2}$ was significant $\left(R^{2}=0.02 ; p=0.05\right)$. The relationship of these parameters is expressed graphically in Figure 1.
All samples of kidney tissue of animals in groups B and C were morphologically evaluated. In none of the examined samples pathological changes were found. Cortex and renal medulla from a representative kidney are displayed in Figure 2.

\section{Discussion}

The ethiopathogenesis of adverse interactions between kidneys and lung have been addressed in a number of clinical and experimental studies $(4,6,7,11)$. The systemic inflammatory reactions, in combination with natural neurohumoral regulation, are undoubtedly the dominant factors in the pathogenesis of these interactions. Regional functional changes in the renal cortex influence the resulting function of the system and changes in renal function were related to microcirculation, membrane receptors, transporting channels and cell organelles $(5,7,10)$. Renal performance is regulated by signal molecules and influenced by organ, tissue, cell and molecular interactions (12).

Positive pressure mechanical ventilation was undoubtedly an unnatural form of pulmonary ventilation, which periodically changed tidal volumes at the cost of permanent higher intrathoracic pressure. The adverse effects of this strategy included reductions in right ventricle performance, increased pulmonary vascular resistance, pulmonary capillary dysfunction, extravasation of granulocytes in addition to alveolar macrophage activation and the release of inflammatory mediators $(2,3,4,13)$. In the course of mechanical ventilation, volume and transpulmonary pressure are transformed into biological influences by activation of the local inflammatory cascade $(1,2,4,11)$. Mechanical transduction activates transcription and mediator release, inducing local and systemic inflammatory reactions having adverse effects on kidney function $(2,7,10)$. The renal cortical microcirculation is regulated by connexins (12) while endogenous catecholamine directly affects regional perfusion $(8,14)$. Aldosterone affects ion excretion and activates the renin-angiotensin system by induction of angiotensin converting enzyme expression $(7,15)$. The key to the explanation of regional hemodynamic regulation in the kidney is the renin-angiotensinaldosterone system. The lungs are involved in the regulation of its own metabolic activity, i.e. conversion of angiotensin I to angiotensin II. Physical changes that accompany mechanical ventilation and metabolic activity of lungs are activated. The result is loosely circulating vasopressors which affect the regional hemodynamics kidney. The goal of this regulation is preservation of renal perfusion at the cost of sodium and water retention $(6,11,13,14,16,17)$.

The results of our study confirm the fact that the systemic hemodynamics was not significantly affected by mechanical ventilation. In this study, animals were mechanically ventilated for twelve hours at two different tidal volumes, where a relatively minor difference in tidal volume yielded interesting results. For example, the lung mechanics and overall hemodynamics were not significantly modified by different ventilation strategies or the time factor.

Within the first hour of ventilation at $6 \mathrm{ml}^{.} \mathrm{kg}^{-1}$, the alveolararterial oxygen difference improved and dead space was reduced. When compared to spontaneous breathing, renal indices were changed, seen as a reduction in glomerular filtration index, free 
water clearance, fractional excretion of sodium and higher ratio of potassium to sodium in the urine, but urinary output was not affected. After twelve hours, there was a further deterioration in all renal indices including one-hour diuresis.

Within the first hour of ventilation at $10 \mathrm{ml} . \mathrm{kg}^{-1}$, the alveolararterial oxygen pressure difference and oxygenation index were improved. In comparison to spontaneous breathing, one-hour diuresis, glomerular filtration indices, free water clearance and fractional excretion of sodium were lower. Elevation of the potassium/ sodium ratio in urine confirmed the secondary effects of aldosterone. After twelve hours, there was a progressive deterioration in the alveolar-arterial oxygen pressure difference, oxygenation index and renal indices with the exception of free water clearance. During ventilation there were more pronounced changes in the renal parameters monitored, but without morphological evidence of damage to the kidneys.

When both ventilation strategies were compared, it was obvious that the higher tidal volume initially and over time caused more pronounced adverse reactions, including renal dysfunction when compared to ventilation with the lower tidal volume.

\section{Study limitations}

Experimental research has the unique advantage that it is possible to create almost ideally uniform groups of animals constituting biomodels. Twelve hour mechanical ventilation does not correspond to the typical clinical scenario of ICU patients, who are typically ventilated for longer time periods. There are also model and species specific limitations that prevent direct extrapolation of our findings to other species. We failed to raise the respiratory rate in the group of animals ventilated with a lower tidal volume to compensate for minute ventilation in the higher tidal volume group. Direct laboratory testing to verify the activation of the renin-angiotensin-aldosterone system are not implemented for two reasons. One of the reasons is the fact that the ratio of potassium to sodium in the urine has a sufficient argument for evaluation of activity of aldosterone. The second, non-medical reason were the financial limitations and the high cost of the experiment.

\section{Conclusions}

This study showed a causal relationship between renal dysfunction and positive pressure mechanical ventilation with respect to tidal volume and time. The conclusions presented in this experimental study could have implications in the everyday clinical practice.

\section{References}

1. Cook D, Rocker G, Marschall J, Sjokvist P, Dodek P, Griffith L, Freitag A, Varon J, Bradley C, Levy M, Finger S, Hamielec C, McMullin J, Weaver B, Walter S, Guyatt. Withdrawal of mechanical ventilation in anticipation of death in the intensive care unit. N Engl J Med. 2003; 349 (12): 1123-1132.

2. Flori HR, Ware LB., Glidden D., Matthay MA. Early elevation of plasma solubile intercellular adhesion molecule-1 in pediatric acute lung injury identifies patients at increased risk of death and prolonged mechanical ventilation. Pediatr Crit Care Med 2003; 4 (3): 315-321.

3. Haeflinger JA, Nicod P, Meda P. Contribution of connexins to the function of the vascular wall. Cardiovasc Res. 2004; 62 (2): 345-356.

4. Kobr J, Kuntscher V, Třeška V, Moláček J, Vobruba V, Fremuth J, Racek J, Trefil L, Kočová J. Averse effects of the high tidal volume during mechanical ventilation of the healthy lung. An experimental study in pigs. Bratisl Med J 2008; 109 (2): 45-51.

5. Bellomo R, Ronco C, Kellum JA, Mehta RL, Palevsky P. Acute renal failure - definition, outcome measures, animal models, fluid therapy and informations technology needs: The Second International Consensus Conference of the Acute Dialysis Quality Iniciative (ADQI) Group. Crit Care 2004; 8: 204-212.

6. Hering R, Peters D, Zinserling J, Wrigge H, von Spiel T, Putensen C. Effects of spontaneous breathing during airway pressure release ventilation on renal perfusion and function in patients with acute lung injury. Intensive Care Med. 2002; 28 (10): 1426-1433.

7. Hoang JB, Liu M, Easley RB, Britos-Bray MF, Kesari P, Hassoun H, Haas M, Tuder RM, Rabb H, Simon BA. Effects of acid aspirationinduced acute lung injury on kidney function. Am J Physiol Renal Physiol 2008; Feb 6 (epub adhead of print).

8. Chacko Ch. Assessment of renal function in the critically ill - shall we lock beyond predictive equations. Ind J Crit Care Med 2013; 17 (2): 65-66.

9. Jackson PG, Cockcroft P. In. Handbook of Pig Medicine. Saunders Elsevier. 2007. Analgesia, anesthesia, and surgical procedures in the pig; 30241, Diseases of the urogenital system and the mammary gland; 155-165.

10. Liang KV, Williams AW, Greene EL, Redfield MM. Acute decompensated heart failure and the cardiorenal syndrome. Crit Care Med 2008; 36 (Suppl 1): S75-88.

11. Morgan BJ. Vascular consequences of intermittent hypoxia. Adv Exp Med Biol 2007; 618: 69-84.

12. Wölfle SE, Schmidt VJ, Hoepfl B, Gebert A, Alcoléa S, Gros D, de Wit C. Connexin 45 cannot replace the function of connexin 40 in conducting endothelium-dependant dilations along arterioles. Circ Res 2007; 101 (12): 1292-1299.

13. Schmidt VJ, Wölfle SE, Boettcher M, de Wit C. Gap junctions synchronize vascular tone within the microcirculation. Pharmacol Rep 2008; 60 (1): 68-74.

14. Hoste EAJ, Kellum JA. Acute kidney injury: epidemiology and diagnostic criteria. Curr Opin Crit Care 2006; 12: 531-537.

15. Hiro Y, Yoshimoto T, Suzuki N., Sugiyama T, Sakurada M, Takai S, Kobayashi N, Shichiri M, Hirata Y. Angiotensin II receptor type 1-mediated vascular oxidative stress and proinflammatory gene expression in aldosterone-induced hypertension: the possible role of local rennin-angiotensin system. Endocrynology 2007; 148 (4): 1688-1696.

16. Blendea MC, Jacobs D, Stump CS, McFarlane SI, Ogrin C, Bahtyiar G, Stas S, Kumar P, Sha Q, Ferrario CM, Sowers JR: Abrogation of oxidative stress improves insulin sensitivity in the Ren-2 rat model of tissue angiotensin II overexpression. Am J Physiol Endocrinol Metab 2005; 288 (2): 353-359.

17. Quigley R, Alexander SR. Acute renal failure. In. Levin DL. Et al.: Essentials of Pediatric Intensive Care. New York: Churchill Livingstone, 1997: 509-523.

Received November 6, 2013. Accepted May 16, 2014. 